\title{
Effect of a brief online shared reading intervention to support communication skills of children with Autism Spectrum Disorder
}

\author{
Otizm Spektrum Bozukluğu olan çocukların iletişim becerilerini \\ desteklemeye yönelik etkileşimli kitap okuma müdahalesinin \\ etkililiğinin incelenmesi \\ Yusuf Akemoğlu ${ }^{1}$
}

\section{Article History}

Received : 8 April 2021

Revised : 14 September 2021

Accepted : 30 September 2021

Article Type

Research Article

\section{Makale Geçmişi \\ Geliş : 8 Nisan 2021 \\ Düzeltme :14 Eylül 2021 \\ Kabul : 30 Eylül 2021}

\section{Makale Türü}

Arasturma Makalesi

\begin{abstract}
Shared interactive book reading (SIBR) is an evidence-based practice for young children with developmental disabilities such as autism spectrum disorder (ASD). Children with ASD can benefit from structured activities such as SIBR, especially when they are supported by their parents. During SIBR, parents can support their children's language and communication skills by engaging with them around a storybook. Parents can create opportunities for communication by commenting on the story, asking a question, and pointing at the pictures. In the current telepractice (internet-based) study, three parents and three children with ASD participated in the study. In a single-case multiple-baseline across subjects design, parents were trained to use expectant pause and mand-model strategy with their children. Parents' frequency in use of the strategies increased during intervention. All three children increased their initiating and responding behaviors upon their parents' use of strategies.
\end{abstract}

Keywords: Shared reading, Autism, Parent training, Telepractice

Öz: Paylaşıma dayalı etkileşimli kitap okuma tekniği (PEKOT), otizm spektrum bozukluğu (OSB) gibi gelişimsel bozukluk veya yetersizliğe sahip küçük çocuklar için kanıta dayalı bir uygulamadır. OSB'li çocuklar, özellikle ebeveynleri tarafından desteklendiklerinde, PEKOT gibi yapılandırılmış etkinliklerden yararlanabilirler. PEKOT etkinliği esnasında, ebeveynler çocuklarıyla bir hikâye kitabı etrafinda etkileşime girerek çocuklarının dil ve iletişim becerilerini destekleyebilirler. Ebeveynler hikâye hakkında yorum yaparak, bir soru sorarak ve resimlere işaret ederek iletişim için firsatlar yaratabilirler. Bu çalışmanın amacı internet (teleterapi) üzerinden yürütülen bir ebeveyn eğitim programının çocukların dil ve iletişim becerileri üzerindeki etkisi incelemektir. Çalışmada,. Çalışma yöntemi olarak tek-denekli araştırma deseninin kullanıldığı bu çalışmaya üç ebeveyn ve üç OSB'li çocuk katılmıştır. Ebeveynler çocuklarıyla birlikte bekleme süresi ve sözel ipucu stratejilerini kullanmak üzere eğitim almıştır. Müdahale sırasında ebeveynlerin stratejileri kullanma sıklığı arttığı ve her üç çocuğun da iletişim başlatma ve iletişime yanıt verme davranışlarının arttığı gözlenmiştir.

Anahtar Kelimeler: Etkileşimli kitap okuma, Otizm, Ebeveyn eğitimi, Teleterapi 


\section{INTRODUCTION}

Children with autism spectrum disorder (ASD) might have challenges developing and/or using communication skills. Communication skills are essential to request, reject, and protest something or someone. Challenges in communication may lead to lack of friendships and expression problems that may cause problem behaviors. For these reasons, developing and using communication skills effectively are very important. This is especially true for children with ASD (Warren, 2000). The development of communication skills in children with ASD remains a serious challenge for families and professionals. There is a great need for targeted communication interventions. Parents are essential in provision of naturalistic interventions because they can provide important social experiences and opportunities for the child to practice communication skills. Children with ASD may have difficulty in interaction and fewer opportunities for social communication activities such as storybook reading (Akemoglu, Meadan, \& Towson, 2020a). Because communication skills are essential and functional, children with ASD should receive interventions that directly address this area of need. While the communication and language profiles of children with ASD may differ from other children, they have been shown to benefit from interventions that from natural, daily routines, such shared interactive book reading (SIBR).

Early communication interventions are proven to be effective for children with ASD and it is crucial to deliver these interventions as early as possible (Akamoglu \& Meadan, 2018). Researchers reported that children with ASD benefit from early communication interventions that occur early in life, through their daily routines and activities, and with familiar people such as family members. In this regard, parents can be key partners to facilitate these interventions. Parents can learn and implement naturalistic communication teaching (NCT) strategies such as mand-model and expectant pause (time delay) via parent-implemented interventions at home (Akamoglu \& Meadan, 2018). Mand-model is a form of a request for a response, a question, or a choice (Akamoglu \& Meadan, 2019).

Shared interactive book reading (SIBR), is a daily routine and a naturalistic activity in which parents can support language and communication of their children by using the NCT strategies. Reading storybooks with young children (ages between 0-6) is a commonly used strategy to promote language and emergent literacy skills. SIBR is a naturalistic activity in which families have in their routines. Thus, SIBR is an activity in which adults can promote a child's communication skills (Akemoglu \& Tomeny, 2021). In shared reading, the goal is to exchange communication based on balanced interactions between an adult and a child (Akamoglu \& Meadan, 2019). When a child actively participates in shared reading, he or she is more likely to improve communication skills such joint attention, pointing, and responding (Coogle et al., 2018; D'Agostino et al., 2020). In 
addition, shared reading allows the adult to make the activity interactive. For example, the adult can label objects and comment on the story or character in the story to support the child's communication. Moreover, a child can engage in a book by pointing to the title, turning pages, and responding to questions.

SIBR can be an ideal intervention context to increase adult-child communicative interactions and thus improve communication skills of young children with ASD. In SIBR, the adult uses a combination of open-ended questions, choice questions, modeling, and praise to create communication opportunities for the child (Zevenbergen \& Whitehurst, 2003). This makes SIBR a social activity because it is based on adult-child communicative interactions. The adult's role is to engage in a conversation with the child about the story, illustrations and/or the characters presented in the book (Akemoglu \& Tomeny, 2021; Coogle et al., 2018). SIBR requires a reciprocal relationship in which a parent and child exchange communication and interact around the storybook. Therefore, parents can use the SIBR activity to provide language and communication support to their children (Akemoglu et al., 2021; Akemoglu et al. 2020a). In a systematic review of SIBR interventions implemented by parents or teachers for young children with disabilities, Towson and colleagues (2017) examined the implementation fidelity across 30 published DR studies. In their review, they reported that not all studies adhered to SIBR fidelity protocol. The authors suggested that studies should strictly adhere to SIBR techniques and protocol. Recently, Boyle and colleagues (2019) completed a meta-analysis of SIBR interventions conducted with children with ASD. Both parents and other adults (teachers, researchers) were the participants. Results of their analysis indicated positive effects for all language and communication outcomes.

For parents to be able to learn and implement SIBR effectively, they need to receive support from professionals (e.g., researchers or educators). For example, PiCSS (Parent-Implemented Communication Strategies-Storybook; Akamoglu \& Tomeny, 2021) is a program that combines parent training and coaching to support parents in use of the specific NCT strategies such as modeling, mand-model, and time delay (see Akemoglu et al., 2020a, for a detailed description of modeling, mand-model, and time delay). In the PiCSS study, parents received in person training and coaching and learned the use of these strategies. Parent coaching included observations, planning, reflection, and feedback. PiCSS study (Akamoglu \& Tomeny, 2021) revealed positive outcomes in parents' implementation and children's verbal and nonverbal communication.

Although, parents can use SIBR as an ideal context to promote communication skills of young children with ASD, they may need individual support to learn to implement strategies with high quality. These supports can be in person (face-to-face) or online from a distance (telepractice). However, in person support may not always be possible, especially due to crisis such as pandemics 
(e.g., COVID-19 pandemic). In these situations, telepractice can be an alternative and viable option to deliver services and support to families. Telepractice cannot replace in person support and service delivery, but it can be a complimentary service delivery mode. Many researchers reported positive outcomes about the effectiveness of telepractice service delivery (Akemoglu, Muharib, \& Meadan, 2020b; Meadan et al. 2016; Vismara et al. 2013). For example, in their telepractice-based study, Wainer and Ingersoll (2015) reported that children had higher rates of initiations in followup. In another telepractice study, Vismara et al. (2013) found that telepractice was effective to support children's verbal and nonverbal communication.

The current study is part of a series of telepractice-based shared reading interventions conducted with families of children with developmental disabilities. The main purpose of this study was to examine the effect of telepractice-based parent coaching on parents' correct use of NCT strategies with their children with ASD during SIBR. The second purpose of this study was to examine the effect of parent-implemented intervention on children's specific social communication outcomes such as responding and initiating. The following research questions were examined:

1. Is there a functional relation between coaching parents to use specific naturalistic language teaching strategies (mand-model and expectant pause) during SIBR and an increase in their frequency of their strategy use?

2. Does participation in parent-implemented communication strategies increase children's use of communication targets during SIBR?

\section{METHOD}

\section{Participants}

Participants were three children with ASD and their parents. Participants were recruited via early intervention programs and clinics, other early intervention providers, and disability groups in the State of Alabama (United States). Interested parents contacted the researcher. The researcher made eligibility determination based on the following inclusion criteria for participation: (1) chronological age between 3-5 years; (2) diagnosis of ASD based on their Individualized Education Plan; (3) minimally verbal children with a vocabulary of at least 25 words reported by the parent; (4) interest in storybooks; (6) access to high-speed internet. Six parents contacted the researcher and three children with ASD, and their mothers were eligible to participate in the study.

\section{Child Participants}

The three children (two males and one female) who participated in this study ranged in age from 37 to 48 months. Alex was 37 months old; Kyle was 43 months old, and Kelsey was 48 months 
old at the beginning of the study. Alex \& Kyle received ASD diagnosis when they were 28 months old, and Kelsey received her diagnosis when she was 32 months old. All three children were receiving early childhood special education at inclusive early childhood programs. Alex had an expressive vocabulary of 39 words, Kyle had 48 words, and Kelsey had 55 words based on MacArthur-Bates Communication Development Inventory (Fenson et al., 2002) assessment. See Table 1 for more demographic and assessment information.

\section{Parent Participants}

Three mothers participated in the study, and they ranged in age from 29 to 37 years. Kelsey's mother Jenna and Kyle's mother Rita had bachelor's degree and were stay-at-home moms, Alex's mother Peggy had a master's degree and she worked full-time outside of the home. Pseudonym names were used to maintain confidentiality. See Table 2 for demographic information.

Table 1. Child Participants

\begin{tabular}{llll}
\hline Child & Age in months & Ethnicity & MCDI expressive vocabulary \\
\hline Alex & 37 & African American & 39 words \\
Kyle & 43 & White & 48 words \\
Kelsey & 48 & Asian-American & 55 words \\
\hline
\end{tabular}

Note. MacArthur-Bates Communication Development Inventory (Fenson et al., 2002)

Table 2. Parent Participants

\begin{tabular}{lllll}
\hline Parent & Age in years & Ethnicity & Education & Marital Status \\
\hline Jenna & 33 & African American & Bachelor's & Married \\
Rita & 29 & White & Bachelor's & Divorced \\
Peggy & 37 & Asian-American & Master's & Married \\
\hline
\end{tabular}

\section{Setting and Technology}

All baseline, intervention, and maintenance sessions were conducted from a distance over the internet (telepractice). Sessions were planned and scheduled in cooperation with families and the most convenient times were identified. The researcher met with each parent individually via videoconferences (Zoom). The mothers joined the Zoom meetings using their own phones or computers. All sessions were recorded via Zoom. Recorded videos were stored on Box, a storage platform. A technology manual that guides parents on the use of technology (Zoom, video recording, and video uploading) was shared with all three parents via email. 


\section{Storybooks}

The researcher sent storybooks to each family. Two books were used for the baseline and maintenance sessions and four books were used during the intervention sessions. All dyads used the same storybooks for each phase of the study. The books were age appropriate, had more illustration than text, and allowed for communication opportunities between parents and children. Each book had a different story about cars, animals, or other characters.

\section{Research Design}

A single-subject, multiple-baseline design across three parent-child dyads was used (Kazdin, 2011). By using this design, we aimed to examine whether the independent variable (parents' use of SIBR intervention) was effective on teaching children new communication skills. We used a multiple baseline design that introduced the intervention in three points across three subjects which allowed to prevent threats to internal validity (Kazdin, 2011).

\section{Procedures}

\section{Baseline}

During the baseline sessions, parents were provided two books that was different from those used during the intervention sessions. Parents were instructed to "read the book as you normally would." The number of baseline sessions varied across participants and each session lasted 4 min on average.

\section{Intervention}

Target Strategies. Parents learned two strategies: expectant pause and mand-modeling. Expectant pause is a form of waiting expectantly. the parent pauses to give the child an opportunity to initiate communication. The parent must do the following while using expectant pause strategy: point to an illustration on the book, leave a phrase or sentence blank, and look at the child expectantly for at least 5 seconds. For example, the parent points at the picture of a "gorilla", says, "This is a , and the child fills in the blank by saying, "Gorilla." Mand-model is a verbal prompt that is used to elicit responses from the child. It can be used as an open-ended question (e.g., "What do you see on the book?"), a choice question (e.g., "Is this a car or a train?"), or a mand (e.g., "Say 'car").

Parent Training. Parents were taught to use the strategies through didactic training (PowerPoints, handouts), demonstration of implementation, role play and practice. Parents also were provided feedback upon practice with their children across the screen. Parents were given a description of each strategy, shown video examples of each strategy, and practiced using each strategy with the 
researcher during the initial parent coaching session. The parent and researcher talked specifically about the target strategies and ways to implement those target strategies when engaging in storybook reading. The remaining of the training session focused on teaching the parent to use the target strategies effectively.

\section{Procedural Fidelity}

Fidelity of implementation of the training session was measured. A fidelity checklist with all procedural steps of the training was completed by the researcher during each session. A master's student in special education served as the secondary observer and independently completed the checklist. Fidelity of implementation for the training sessions was measured as $100 \%$.

\section{Maintenance}

Maintenance data was collected to assess whether parents continued using the strategies after the intervention and if effects of the intervention continued. Two maintenance sessions were conducted two weeks after the intervention ended. The procedures were identical to the baseline sessions and parents were provided the same books as in baseline.

\section{Social Validity}

Social validity was measured by having parents complete a written questionnaire after the intervention phase to indicate whether the intervention was acceptable and feasible for them and whether they would maintain using the strategies. All three parents completed a Likert-type scale questionnaire about training, strategies, and outcomes. Parents were also asked if they enjoyed the intervention with their children.

\section{Observational Data Coding}

Each strategy (expectant pause and mand-model) was tally coded based on occurrence using a coding form. Thus, we collected data on how many times the parent used each strategy within each phase. Child data was collected on verbal (e.g., responding) and nonverbal (e.g., gesturing, pointing) initiations and responses. Child responses were coded per occurrences upon the parent's use of a strategy Each number of child response or initiation behavior was tally coded and recorded to measure frequency.

\section{Interobserver Agreement (IOA)}

IOA was collected on observed data, and it was assessed by coding the data by two team members. The author (researcher) coded all the observational parent and child data based on a coding manual. Then, the author trained a secondary coder (master's student) to code the data. To train the 
secondary coder, the author met with the secondary coder to code a video together. Next, he assigned her another video to code, and they met and discussed the agreements and disagreements. Then, the secondary coder was assigned $30 \%$ of all the sessions. IOA calculation formula was agreements divided by agreements and disagreements and multiplied by 100 . Overall, IOA ranged between $80 \%$ and $96 \%$ with a mean of $88 \%$.

\section{Data Analysis}

Parents' implementation of strategies was specifically measured for (a) expectant pause; and (b) mand-model. Visual analysis was conducted to analyze if there a functional relation between the intervention and parent and child outcomes (Kazdin, 2011). For example, visual inspection (analysis) of the slope helped us to interpret the data trends. Visual inspection of changes in the slope was used to measure variability in the data. Levels and intervention effect was measured by looking at the means of the intervention sessions.

\section{Ethical Approval of Research}

All rules stated to be complied with within the scope of "Higher Education Institutions Scientific Research and Publication Ethics Directive" were followed in this study. None of the actions mentioned under the heading of "Actions Against Scientific Research and Publication Ethics", which is the second part of the directive, have been carried out.

\section{Ethics committee approval information (Institutional Review Board approval):}

Ethical approval committee name $=$ The University of Alabama

Date of ethical approval decision= December 19, 2019

Ethical approval document number=18-011-R1 and 20-03-3411

\section{RESULTS}

\section{Parent Results}

Figure 1 depicts that Alex and Kelsey's parents' baseline data were relatively stable, whereas Kyle's parent had more variability in baseline data. Kelsey's parent had the lowest baseline data level. Immediate increases in expectant pause and mand-modeling strategies were observed across all three parents. While Alex's parents demonstrated the least immediate gain, Kyle's parent had the largest gain. Kelsey's parent demonstrated a higher data level in mand-model strategy compared with expectant pause. 


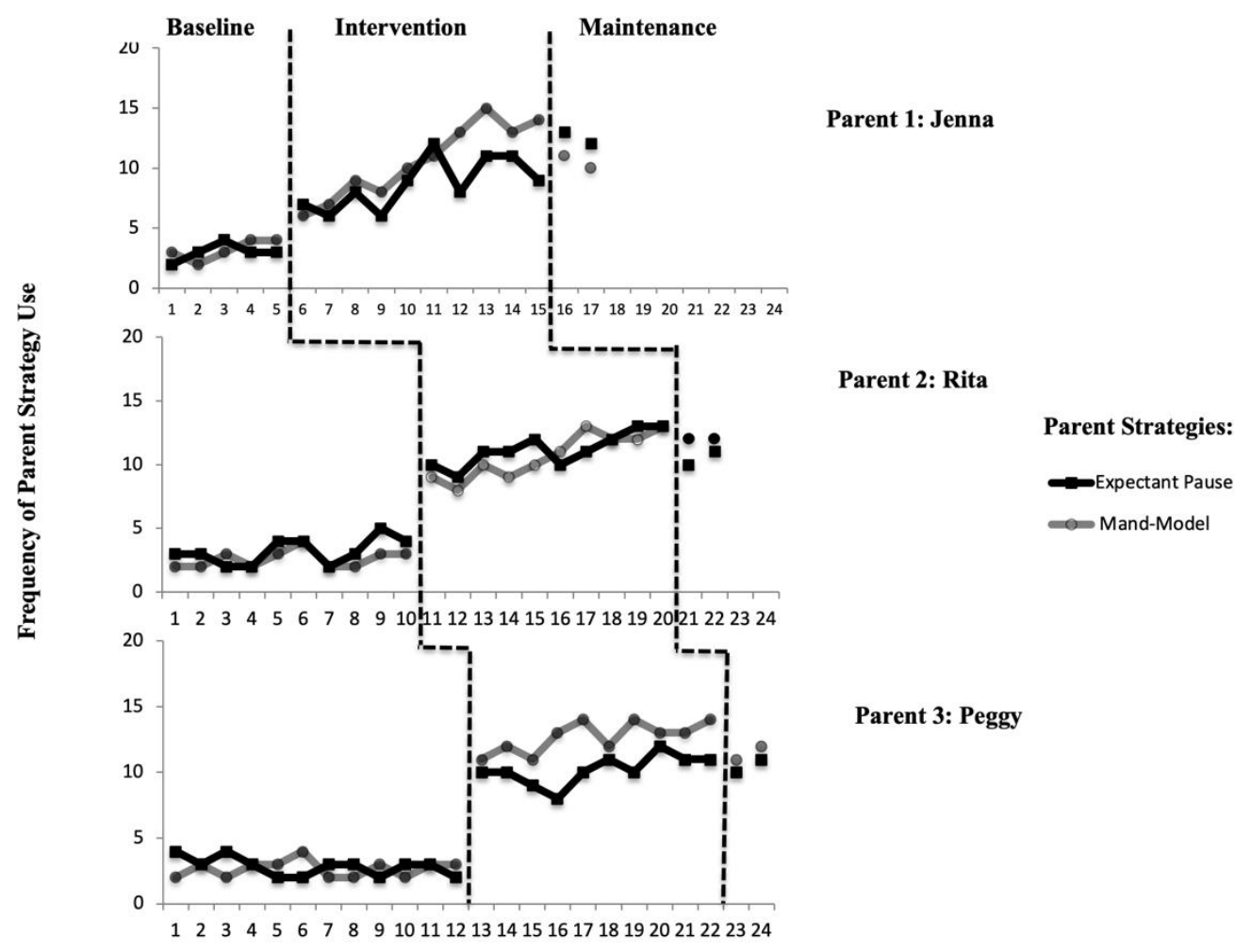

Figure 1. Frequency of Parent Communication Strategy Use Across Baseline, Intervention and Maintenance Phases.

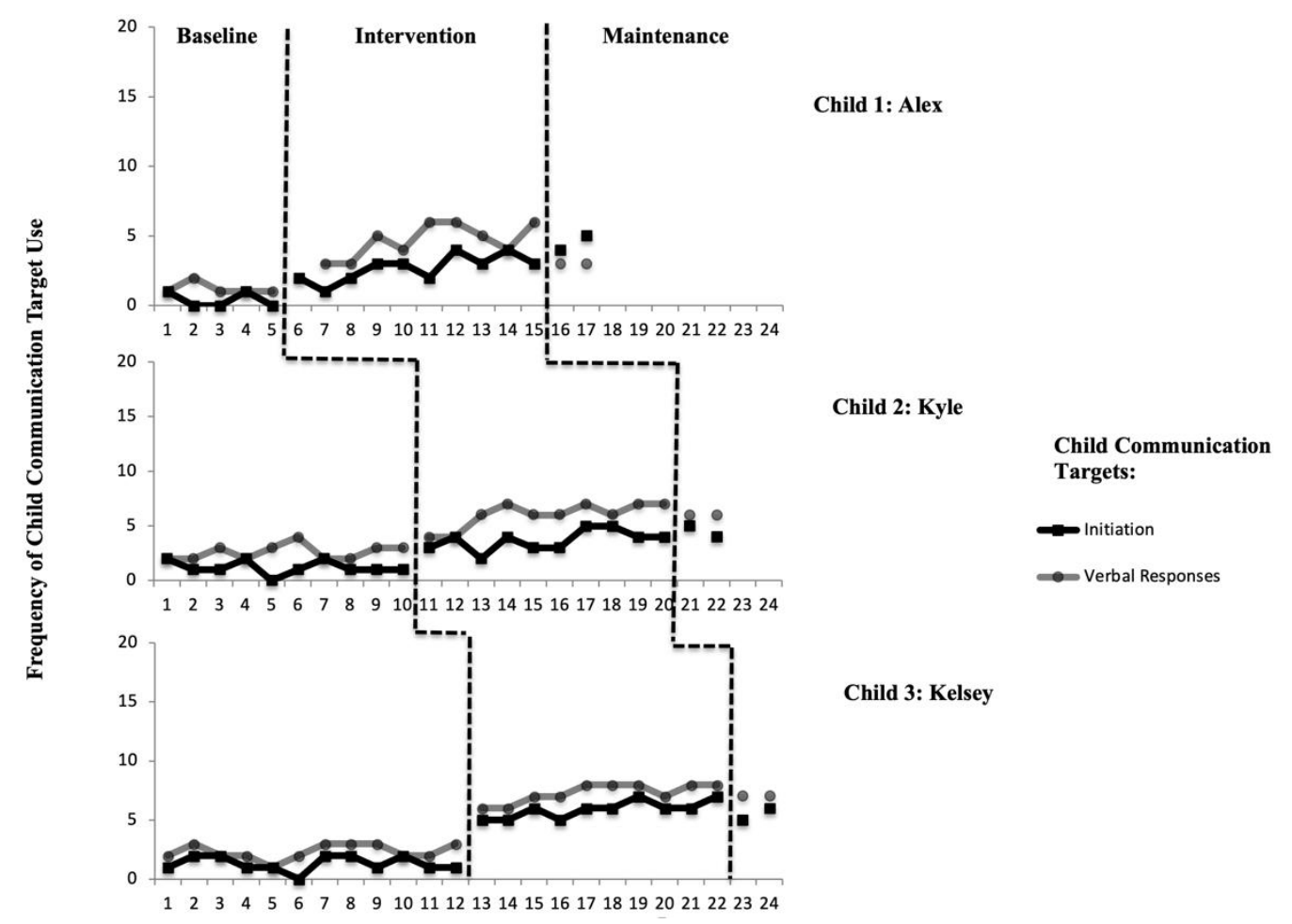

Figure 2. Frequency of Child Communication Behaviors Across Baseline, Intervention and Maintenance Phases. 
As demonstrated through visual inspection, all three parents consistently increased their frequency of strategy use. While Alex's mother had an increasing trend during intervention, Kelsey's mother made the largest overall level gain in intervention phase compared to baseline level. She had an overall increasing trend with a higher level in mand-model strategy. As shown in Figure 1, all three parents demonstrated some decrease in their mand-model strategy use in the maintenance phase. However, their use of expectant pause and mand-model strategy was at the same average mean as in the intervention phase. Overall, there was a clear increase in parents' frequency of strategy use from baseline to intervention. Parents also maintained their frequency of strategy use at a higher rate than baseline level during the maintenance phase.

\section{Child Results}

Children's communication targets were (a) initiation and (b) verbal responses. Children's dependent variables (communication targets) were measured across all phases. Regarding their communication acts in responses and initiations, although they had some variability, all three children demonstrated increases both in responses and initiations with response rates being higher than the initiations. The difference between responses and initiations was not significant yet still expected due to the nature of ASD.

As shown in Figure 2, all three children had stable baseline data with limited variability. In terms of mean frequency, Alex's mean level was the lowest with one or fewer communication skills. Although Alex and Kyle's initiation data had minimal immediate increases from baseline to intervention during intervention, their data demonstrated an upward trend. Moreover, their mean frequencies were higher in intervention compared to the baseline phase. As such, while Alex's response data showed an increase and variability during intervention phase, his data was followed with a decrease during maintenance phase. Similarly, Kyle's response act data showed an upward trend, and his level was higher during intervention compared to the baseline phase. Kyle's frequency of targets was at a steady level. Kelsey's data on communication targets were followed with upward trends during intervention with the level of initiation being lower than the response level. She maintained both targets in the maintenance phase.

\section{Social Validity Data}

The satisfaction survey was completed by all three parents. The participating parents reported satisfaction with goals, procedures, and outcomes. The parents noted that the training they received was effective to enhance their knowledge and refine their implementation skills. They also noted that they observed positive progress in their children's communication outcomes. All three 
participating parents indicated that they enjoyed the reading sessions with their children and felt that their children also were more engaged.

\section{DISCUSSION}

Parents were taught to increase their use of two target strategies. Results were analyzed by observing changes in frequency of target strategy use across phases. Visual inspection of parent data provides information about the correlation between their use of strategies and their children's data in initiation and responding.

The patterns demonstrated by three parents were notable changes in use of the target strategies. All three parents increased their frequencies of strategy use overall. A steep upward trend in targeted communication rates were observed across all three children. Their parents demonstrated similar trends with variable upward trends in implementation of expectant pause and mand-model strategies. However, unlike their parents' immediate increases in levels for target strategies, Alex and Kyle's frequency of communication skill use had an increase in slope later in the intervention phase. That was because at the beginning of the intervention, both children were not fully attending to the storybooks and did not frequently respond to the parents' repeated attempts to gain attention. Alex's data was the most variable across all children. Notably, Alex's mother also had a similar variable data in use of expectant pause strategy. Moreover, she had a slight variability of mand-model strategy at the end of the intervention phase. These patterns indicates that there is functional relation between parent's use of the strategies and child's communication skills.

Differences in parents' response to the expectant pause and mand-model strategies are likely due to a combination of various factors, which may include their overall motivation, comfort level with one of the strategies, and children's response to their use of the strategies (Akemoglu et al., 2020). Furthermore, certain strategies may be easier to implement, or perhaps certain storybooks provide more opportunities to use specific strategies (D'Agostino et al., 2020).

Coaching was an important factor in improving the parents' fidelity of implementation. While training enhances the participants' knowledge, coaching provides individual support to increase their performance. In this regard, coaching is responsible for individual performance differences. Other researchers have reported similar outcomes and noted the efficacy of coaching (Akamoglu \& Meadan; 2019; Akemoglu \& Tomeny, 2021; Meadan et al., 2014).

In summary, all three parents and children made progress in their level of strategy and communication target use. The detectable changes in children's use of communication targets 
were observed with relatively lower levels as opposed to level changes in parents' use of strategies. The fact that the three of the children had low frequencies of target use across the study may be due to a variety of factors. Firstly, the intervention may not have been long enough to support changes in children's use of communication targets. Children with ASD require intensive intervention for long periods of time to impact their ability to use language and communication (Fleury \& Schwartz, 2017). Furthermore, young children with ASD generally take longer to learn and generalize language skills. Secondly, SIBR interventions may be an effective way to change communication behavior (Towson et al., 2017). This intervention was valuable as the focus of the intervention was to increase parents' abilities to facilitate social interactions through SIBR and thus increasing opportunities for children with ASD to participate in this important social-communicative activity.

There are three ways about how the present study adds and expands prior research. First, the findings show that telepractice can be a viable option to support parents and their children (Akemoglu et al., 2021; Meadan et al., 2016). Second, the findings suggest that SIBR can be a suitable context for parent-implemented communication interventions. Yet, while using SIBR, researchers and/or educators might have to incorporate "child engaging" prompts (see Akemoglu et al., 2020a). Similar findings were reported in the literature (D'Agostino et al., 2020; Lorio \& Woods, 2020). Third, all three parents learned to implement the strategies and reported satisfaction with telepractice procedures (online training and coaching) and outcomes. The parent reports align with outcomes of other parent-implemented shared reading studies (Akemoglu et al., 2019).

\section{Implications}

This study supports two implications. Firstly, the results support the other findings that telepractice based parent-implemented shared reading interventions can promote children's communication skills (Akamoglu \& Meadan, 2018). Practitioners that work with families should consider alternative online delivery methods to reach to families from a distance.

Secondly, parents can use SIBR as a daily context to provide communication support for their children. SIBR can be a tool for parents to facilitate the reciprocal interaction with their children. To elicit responses, parents might need to use additional prompts and make SIBR a predictable routine for their children (Lorio \& Woods, 2020). 


\section{CONCLUSION}

Providing support to parents and teaching them how to use communication teaching strategies can help them make the SIBR activity successful. Telepractice services are important and can serve as a viable option to support parents. Practitioners can support families from a distance via the internet and provide them quality services. The following should be considered while providing telepractice based services: (a) be familiar with technology, (b) have access to highspeed internet, and (c) be flexible and available to the family.

\section{REFERENCES}

Akemoglu, Y., Garcia Grau, P., Meadan, H. (2019). Using masked raters to evaluate social validity of a parent-implemented communication intervention. Topics in Early Childhood Special Education. 39(3), 144-155.

Akemoglu, Y., Hinton, V., Laroue, D., \& Jefferson, V. (2021). Parent-Implemented Shared Reading Intervention via Telepractice. Journal of Early Intervention. Advanced online publication, 121. DOI: $10.1177 / 10538151211032211$

Akamoglu, Y., \& Meadan, H. (2019). Parent implemented communication strategies during storybook reading. Journal of Early Intervention, 41(4), 300-320.

Akamoglu, Y., \& Meadan, H. (2018). Parent-implemented language and communication interventions for children with developmental delays and disabilities: A scoping review. Review Journal of Autism and Developmental Disorders, 5(3), 294-309.

Akemoglu, Y., Muharib, R., \& Meadan, H. (2020b). A systematic and quality review of parentimplemented language and communication interventions conducted via telepractice. Journal of Behavioral Education, 29, 282-316.

Akemoglu, Y., Meadan, H., \& Towson, J. (2020a). Embedding naturalistic communication teaching strategies during shared interactive book reading for preschoolers with developmental delays: A guide for caregivers. Early Childhood Education Journal. 48, 759-766.

Akemoglu, Y., \& Tomeny, K. (2021). A parent-implemented shared reading intervention to promote communication skills of preschoolers with autism spectrum disorder. Journal of Autism and Developmental Disorders, 51(8), 2974-2987. 
Boyle, S. A., McNaughton, D., \& Chapin, S. E. (2019). Effects of shared reading on the early language and literacy skills of children with autism spectrum disorders: A systematic review. Focus on Autism and Other Developmental Disabilities, 34(4), 205-214.

Coogle, C., Floyd, K. K., \& Rahn, N. L. (2018). Dialogic reading and adapted dialogic reading with preschoolers with autism spectrum disorder. Journal of Early Intervention, 40(4), 363-379.

D’Agostino, S. R., Dueñas, A. D., \& Plavnick, J. B. (2020). Increasing social initiations during shared book reading: An intervention for preschoolers with autism spectrum disorder. Topics in Early Childhood Special Education, 39(4), 213-225.

Fenson, L., Marchman, V., Thal, D., Dale, P., Reznick, S., \& Bates, E. (2002). MacArthur-Bates Communicative Development Inventories (MCDI; $2^{\text {nd }}$ ed.). Baltimore, MD: Brookes.

Fleury, V. P., \& Schwartz, I.S. (2017). A modified dialogic reading intervention for preschool children with autism spectrum disorder. Topics in Early Childhood Special Education, 37, 16-28.

Lorio, C. M., \& Woods, J. J. (2020). Multi-component professional development for educators in an Early Head Start: Explicit vocabulary instruction during interactive shared book reading. Early Childhood Research Quarterly, 50, 86-100.

Meadan, H., Angell, M. E., Stoner, J. B., \& Daczewitz, M. E. (2014). Parent-implemented socialpragmatic communication intervention: A pilot study. Focus on Autism and Other Developmental Disabilities, 29, 95-110.

Meadan, H., Snodgrass, M. R., Meyer, L. E., Fisher, K. W., Chung, M. Y., \& Halle, J. W. (2016). Internet-based parent-implemented intervention for young children with autism: A pilot study. Journal of Early Intervention, 38, 3-23.

Kazdin, A. E. (2011). Single-case research designs: Methods for clinical and applied settings (2nd ed.). New York: Oxford University Press.

Roberts, M. Y., \& Kaiser, A. P. (2012). Assessing the effects of a parent-implemented language intervention for children with language impairments using empirical benchmarks: A pilot study. Journal of Speech, Language, and Hearing Research, 55, 1655-1670.

Rush, D. D., \& Shelden, M. L. (2011). The early childhood coaching handbook. Baltimore, MD: Brookes. 
Towson, J. A., Fettig, A., Fleury, V. P., \& Abarca, D. L. (2017). Dialogic reading in early childhood settings: A summary of the evidence base. Topics in Early Childhood Special Education, 37(3), 132-146.

Unholz-Bowden, E., McComas, J. J., McMaster, K. L., Girtler, S. N., Kolb, R. L., \& Shipchandler, A. (2020). Caregiver training via telehealth on behavioral procedures: A systematic review. Journal of Behavioral Education, 29(2), 246-281.

Zevenbergen, A. A., \& Whitehurst, G. J. (2003). Dialogic reading: A shared picture book reading intervention for preschoolers. In A. van Kleeck, S. A. Stahl, \& E. B. Bauer (Eds.), On reading books to children: Parents and teachers (pp.177-200). New Jersey: Lawrence Erlbaum Associates.

Vismara, L. A., McCormick, C., Young, G. S., Nadhan, A., \& Monlux, K. (2013). Preliminary findings of a telehealth approach to parent training in autism. Journal of Autism and Developmental Disorders, 43(12), 2953-2969.

Warren, S. F. (2000). The future of early communication and language intervention. Topics in Early Childhood Special Education, 20, 33-37.

Whalon, K., Martinez, J. R., Shannon, D., Butcher, C., \& Hanline, M. F. (2015). The impact of reading to engage children with autism in language and learning (RECALL). Topics in Early Childhood Special Education, 35, 102-115.

Whitehurst, G. J., Arnold, D. H., Epstein, J. N., Angell, A. L., Smith, M., \& Fischel, J. E. (1994). A picture book reading intervention in day care and home for children from low-income families. Developmental Psychology, 30, 679-689. doi:10.1037/0012-1649.30.5.679

Whitehurst, G. J., \& Lonigan, C. J. (1998). Child development and emergent literacy. Child Development, 69, 848-872. 